\title{
EDITORIAL
}

\section{Anticoncepción de emergencia: Sólo un síntoma más}

Mucho se ha discutido últimamente acerca de la "píldora del día después", entrecruzándose en el debate los argumentos científicos con los religiosos, morales, políticos y hasta económicos. Sin desconocer la importancia del tema, hay que decir que estamos ante una discusión pública que es coyuntural a un problema estructural de larga data. Una vez más, un tema técnico y de salud pública está siendo sometido a análisis de tipo valórico que, dado el avance de la ciencia y los conocimientos sobre los mecanismos de funcionamiento de la anticoncepción de emergencia, hacen la discusión peregrina.

Sin duda, es respetable que haya grupos religiosos y políticos con opinión, pero igualmente lo es la postura de quienes piensan de manera distinta. No en vano la libertad de expresión y la de elección son derechos consagrados constitucionalmente para todos los chilenos.

Desde el punto de vista técnico y científico, es público que la Organización Mundial de la Salud y organismos intemacionales no gubernamentales dedicados a temas de reproducción humana coinciden en que el levonorgestrel como anticonceptivo de emergencia no es abortivo. En Chile, científicos de renombre, como los doctores Croxatto y Zegers, han sido categóricos en sus afirmaciones sobre el particular. Desde este punto de vista, entonces, no debería haber más que hablar.

Sin embargo, la discusión se há llevado por un cauce que va más allá de las válidas opiniones respecto del uso de un anticonceptivo en caso de violaciones y de su entrega gratuita en los consultorios. Lo que está en cuestión es el derecho de las personas a disfrutar de una sexualidad plena y sana, derecho que el Estado tiene el deber de garantizar.

Cabe destacar que Chile es signatario de la Conferencia de El Cairo sobre Población y Desarrollo, realizada en 1994, donde por consenso de los países participantes se aprobó un plan de trabajo. Si bien éste no es obligatorio, se entiende que si un gobierno lo firma al menos intentará ponerlo en práctica. Hasta el momento, el Estado chileno no ha cumplido con este compromiso; no existe un programa de salud sexual y reproductiva tal como lo define la comunidad internacional y al alcance de todos, sino sólo un programa de la mujer que incorpora actividades bajo el mismo concepto, pero que está limitado desde su concepción.

Estudios realizados por la Escuela de Salud Pública de la Universidad de Chile en distintos sectores del país comprueban lo que la comunidad científica internacional ha dicho varias veces: la población chilena - especialmente los jóvenes- no recibe en los servicios de salud ni en ninguna parte, la información ni los insumos que le permitan llevar una sexualidad libre y sin riesgos. La poca información que poseen y que pueden entregar los profesionales de esos servicios es extremadamente limitada, y con mucha frecuencia influida por sus creencias y convicciones personales.

Los orígenes de tan grave situación son múltiples. Sin embargo, se pueden resumir en una falta de decisión para enfrentar a los grupos políticos y religiosos que pretenden imponer una concepción del mundo y de la sexualidad al resto de la población. Si esto no fuese así, ya tendríamos un programa de salud sexual y reproductiva moderno, como lo tienen otras naciones a las que consideramos menos desarrolladas.

Es grave porque la falta de visiones políticas implica que los procesos de enseñanza de estos temas adolecen de serias falencias. Como anécdota, cabe señalar que los alumnos que ingresaron en 1994 a la carrera de Medicina nunca oyeron en las aulas hablar de salud sexual y reproductiva y menos de la Conferencia de El Cairo que como dijéramos, se celebró ese año. Sí 
tuvieron lecciones de anatomía y conocieron a fondo el funcionamiento del aparato reproductor humano, pero no analizaron el tema desde el concepto de salud pública y social que, obviamente, es central a la actual discusión.

Chile es un país en transición epidemiológica y demográfica avanzada, lo cual lo hace tener características de enfermedades y de estructura de población similares a los países desarrollados. Esto ha conducido a cambios profundos en los problemas que aquejan a su población. Por otro lado, tenemos muy buenos indicadores en salud, gracias a una política secular de salud pública que ha trascendido las distintas tendencias políticas.

A pesar de ello, no somos capaces de reconocer que hay ciertas áreas de la salud pública que es necesario abordar, como la salud sexual y reproductiva, que debe ser vista considerando la sexualidad como un fenómeno normal. Pero nos encontramos con que la formación de profesionales está enfocada a "curar enfermos", lo que nos muestra en forma dramática la urgencia de crear mecanismos que permitan dar salud más que combatir la enfermedad.

Es claro que estamos en una situación que merece una preocupación mayor. En otras palabras, la discusión sobre la píldora es sólo un síntoma de una profunda limitación que sufre el país y que tiene que ver, entre otros factores, con la formación de los profesionales en salud en las áreas analizadas, más que con discutir por la prensa o llevar a los tribunales un tema que científicamente está resuelto.

Pero aún es tiempo de enmendar rumbo. El actual programa de la mujer debe ser cambiado a uno efectivo de salud sexual y reproductiva; el personal de salud ha de ser reentrenado; la salud tiene que ser concebida como preventiva y no meramente curativa; la gestión de servicios debe ser reorientada con una visión que refleje los cambios demográficos y epidemiológicos que vive el país.

En suma, tenemos que preocuparnos de dar salud a los chilenos, asumiendo que la sexualidad es una oportunidad para tener una vida mejor y mejorar las relaciones entre las personas. Es el primer paso para la creación de la vida (hecho reconocido por todas las religiones), por lo cual hay que darle la dimensión que corresponde.

Si las autoridades y todos los actores involucrados partieran desde estas premisas, probablemente la sociedad sería mucho mejor: más madura, menos prejuiciada, más tolerante, menos agresiva, más integradora, menos descalificadora. 